\title{
EMERGENCY MEDICINE RESIDENTS LACK THE NECESSARY AUTONOMIC NERVOUS SYSTEM BALANCE AND SHORT RELAXATION TECHNIQUES ARE INSUFFICIENT TO SOLVE THIS
}

\author{
Martynas Gedminas, Lukas Neimanas², Dinas Vaitkaitis, Nedas Jasinskas, Viktoras Šaferis ${ }^{3}$, \\ Kęstutis Stašaitis ${ }^{1}$, Paulius Dobožinskas ${ }^{5}$, Aurimas Mačiukas ${ }^{4}$ \\ ${ }^{1}$ Department of Emergency medicine, Lithuanian University of Health Sciences, ${ }^{2}$ Medical Academy, \\ Lithuanian University of Health Sciences, ${ }^{3}$ Department of Physics, Mathematics and Biophysics, \\ Lithuanian University of Health Sciences, ${ }^{4}$ Lithuanian Sports University, ${ }^{5}$ Department of Disaster \\ medicine, Lithuanian University of Health Sciences
}

Key words: heart rate variability, burnout, emergency medicine, mindfulness, stress resilience, residency training, human performance optimisation.

\begin{abstract}
Summary
Study objective. Heart rate variability (HRV) is an objective, easy-to-obtain parameter that can be used to monitor person's balance of autonomous nervous system, which in turn decides one's ability to cope with stress. HRV has been used extensively in professional athletes and the military with the purpose of performance optimisation and burnout prevention. The aim of our study was to investigate the balance of EM residents' autonomic nervous system, as indicated by fluctuations in day-to-day HRV readings, and the feasibility of short relaxation techniques to increase their stress-resilience.

Methods. We conducted a two-month long prospective cross-over double blinded randomized study. Computer randomization was used to divide the EM residents into intervention (A) and control (B) groups. Controls were instructed to listen to a $12 \mathrm{~min}$. relaxation audio file every morning, while the intervention group was equipped with a $12 \mathrm{~min}$. guided meditation that combined rhythmic breathing and attention focusing techniques. After one month, crossover of the interventions took place.

Results. After pooling pre-shift and post-shift HRV data, we identified differences of statistical significance with post-shift HRV readings being higher $(p=0.028, p<0,05)$. Individual HRV trend analysis showed significant fluctuations in day-to-day HRV readings. We could not identify the impact of short re-
\end{abstract}

laxation techniques on the EM residents HRV trends. Conclusion. Our findings suggest the lack of autonomic nervous system balance among EM residents, as indicated by big fluctuations in their day-to-day HRV trends. During the course of the study, the HRV reading fluctuations did not stabilise, indicating the limited use of our selected short relaxation techniques to increase residents' stress resilience. We also identified paradoxical findings of higher post-shift HRV readings which could true be due to unique population in the setting of EM.

\section{Introduction}

In order to provide complex treatments in humane and efficient manner, contemporary health care specialists are required to demonstrate maximum levels of empathy, honesty and expertise. Naturally, these values are incorporated into medical training programs. However, the clinical environments expose junior doctors to much different reality. Death, suffering, continuous multitasking, night shifts and hectic pace often lead to unfavourable emotional and health states in medical trainees [1]. This results in growing burnout rates among physicians and nurses [2-4]. It is well established that empathy decreases during the course of medical education [5-7].

If we want future physicians to excel in their training and to flourish as specialists, more attention needs to be paid at their health, mental and emotional well-being. To achieve this, we need tools that would allow junior doctors to cope with growing challenges of the medical field. A good example is the US Department of Defence (DOD). Acknowledging the importance of human factors in mission success, the military came up with concepts of Precision Performance, 
Human Performance Optimization (HPO) and Total Force Fitness $[8,9]$. These paradigms emphasize multi-monitoring of various parameters and personalisation of recommendations for nutrition, hydration, psychological, spiritual, social, medical and other domains of an individual's life in order to create the "Shield of Health". According to HPO, human being is recognised as complex system of systems, where multiple aspects have to be taken into account in order to achieve optimal performance and mission success.

Similar paradigm shift needs to happen in healthcare and medical education. We are spending billions on multimodal monitoring approaches for our patients, leaving the inner states of doctors, i.e. life $\&$ death decision makers, completely ignored. Luckily, there are objective, easy-to-obtain parameters, like heart rate variability (HRV), which can demystify one's inner well-being. HRV can monitor person's balance of autonomous nervous system, which decides the ability to cope with physical, cognitive and emotional stress [10-13].

Emergency medicine (EM) residents and physicians are among those with the highest risk of developing stress related health illnesses $[14,15]$. Being stress resilient is of vital importance in the field of EM, where quickly making difficult decisions while managing multiple patients is the norm of practice.

Table 1. Baseline participant characteristics.

\begin{tabular}{|l|l|l|}
\hline \multicolumn{2}{|l|}{ Characteristic } & \multicolumn{2}{l|}{ Group } \\
\cline { 2 - 3 } & $\begin{array}{l}\text { A - Intervention } \\
\text { at the beginning }\end{array}$ & $\begin{array}{l}\text { B - Control at the } \\
\text { beginning }\end{array}$ \\
\hline $\begin{array}{l}\text { Sex } \\
\text { Male, } n(\%)\end{array}$ & $3(37,5 \%)$ & $2(25 \%)$ \\
\hline Age in years, mean (SD) & $27,0(2,07)$ & $25,88(1,25)$ \\
\hline $\begin{array}{l}\text { Resident status } \\
\text { Junior, } n(\%)\end{array}$ & $4(50 \%)$ & $6(75 \%)$ \\
Senior, $n(\%)$ & $4(50 \%)$ & $2(25 \%)$ \\
\hline $\begin{array}{l}\text { Practising mindfulness, medita- } \\
\text { tion or prayer } \\
\text { "Never", } n(\%) \\
\text { "Sometimes", } n \text { (\%) }\end{array}$ & $5(62,5 \%)$ & $6(75 \%)$ \\
\hline Usual sleep hours, mean (SD) & $3(37,5 \%)$ & $2(25 \%)$ \\
\hline $\begin{array}{l}\text { Night shifts per month, median } \\
\text { (range) }\end{array}$ & $7,0(1,04)$ & $6,56(1,45)$ \\
\hline $\begin{array}{l}\text { Monthly workload (hours), mean } \\
\text { (SD) }\end{array}$ & $175,0(20,7)$ & $3(2-4)$ \\
\hline $\begin{array}{l}\text { Religious } \\
\text { No, } n(\%)\end{array}$ & $6(75 \%)$ & $6(75 \%)$ \\
\hline $\begin{array}{l}\text { Active smoker } \\
\text { Yes, } n(\%)\end{array}$ & $2(25 \%)$ & $5(62,5 \%)$ \\
\hline $\begin{array}{l}\text { Coffee intake } \\
\text { "Several cups a day", } n(\%)\end{array}$ & $5(62,5 \%)$ & $4(50 \%)$ \\
\hline $\begin{array}{l}\text { Alcohol intake } \\
\text { "Once a week or more", } n(\%)\end{array}$ & $3(37,5 \%)$ & $3(37,5 \%)$ \\
\hline
\end{tabular}

The aim of our study was to investigate the balance of EM residents' autonomic nervous system, as indicated by fluctuations in day-to-day HRV readings, and the feasibility of short relaxation techniques (listening to relaxation music and performing a guided meditation) to increase their stressresilience.

\section{Methods}

Study design. We conducted a two-month long prospective cross-over randomized blinded study in the Lithuanian University of Health Sciences. The study took place between October and November in 2016.

Procedure. Consent for the study was obtained from local bioethics committee.

All EM residents were invited to the study. Sixteen agreed to participate. In a pre-study meeting, residents were instructed how to perform the relaxation exercises, how to use HRV monitoring devices and the necessary smart phone application. Instructions were also sent to each member personally via email. Research team consisted of the residency coordinator, senior EM resident and a medical student, who was collecting and blinding data prior to presenting it to

Figure 1. Average pre-shift HRV values $\mathrm{X}$ - meassurement days, $\mathrm{Y}$ - HRV

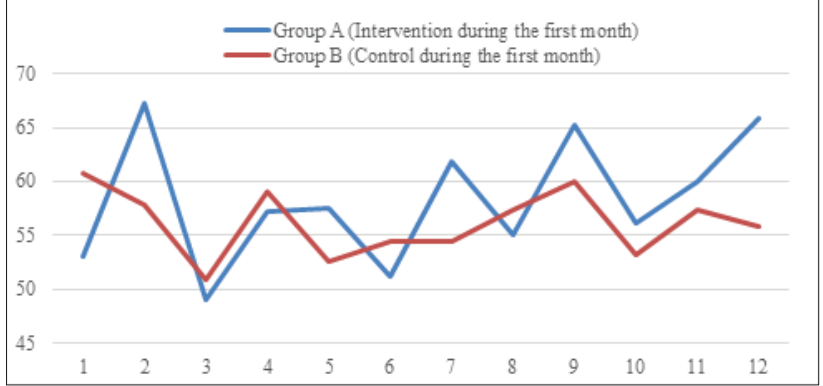

Figure 1. Average pre-shift HRV values.

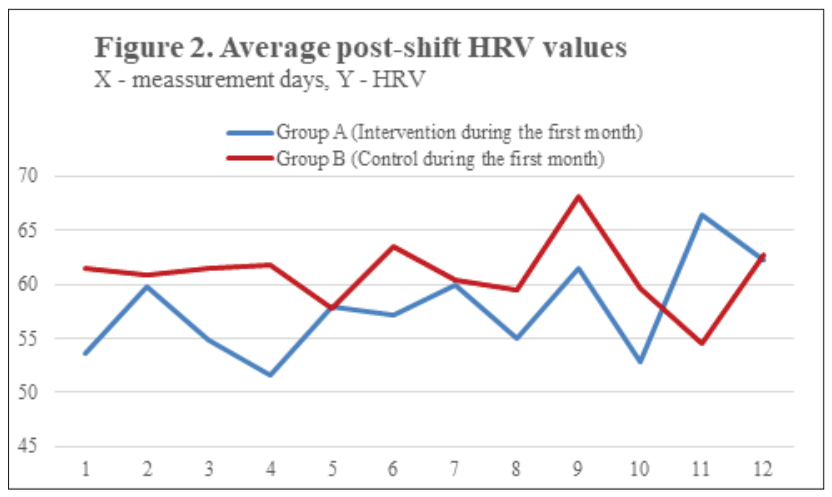

Figure 2. Average post-shift HRV values. 


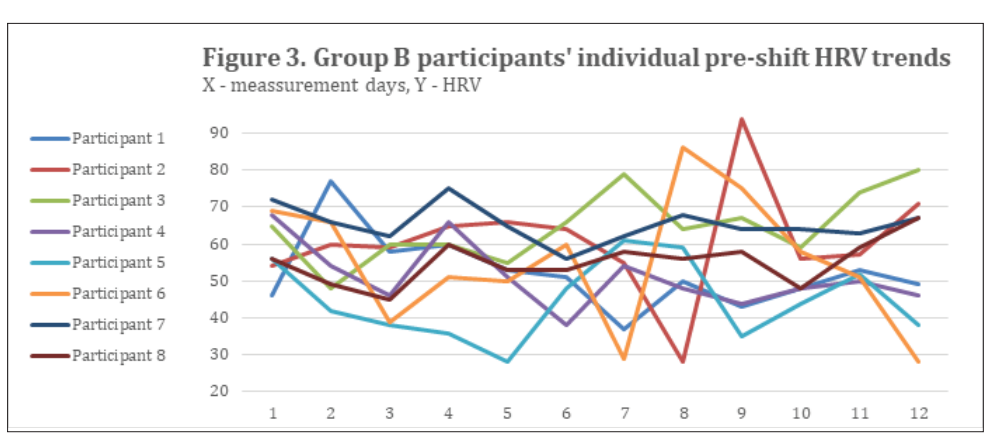

Figure 3. Group B participants' individual pre-shift HRV readings trends.

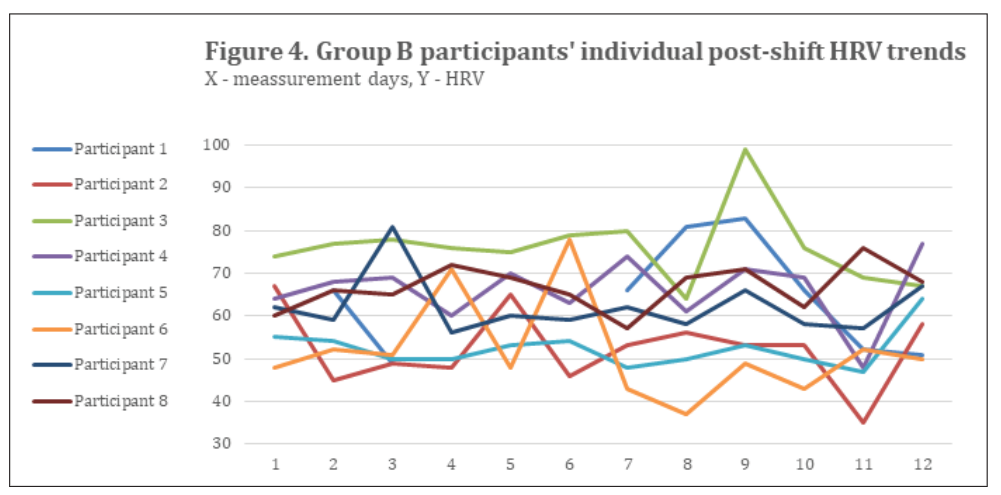

Figure 4. Group B (Control at the beginning) individual pre-shift HRV readings of the first study month.

other investigators.

Computer randomization was used to divide participants into intervention (A) and control (B) groups. Controls received a 12 min. long relaxation music audio file, while the intervention group was equipped with a $12 \mathrm{~min}$. long guided meditation that combined rhythmic breathing and attention focusing techniques. Members were instructed to perform relaxation exercise once every morning. They were also asked not to share any information with other study members. After one month of the study, participants were dispatched with new audio files and were instructed to practise these relaxation exercises. They were not aware whether the new audio files were already used by other members.

Chest-strap HRV monitoring devices (Wahoo Tickr X Heart Rate Monitor(C) and smartphone application Elite HRV(C) were used to collect the study data. The readings were taken on six random day-time emergency room (ER) shifts per month. The participants were informed (email and SMS) before the start of the shift to take the measurements. They were done before the start of the shift and right after it finished, in a silent room where there would be no interruptions.

Statistical analysis. Statistical analysis was performed using IBM SPSS Statistics for Windows, Version 24 (Armonk, NY: IBM Corp. Software). Descriptive characteristics were summarized and presented as absolute values, percentages, means \pm standard deviation. Comparisons between groups were performed by using Mann-Whitney (U), Wilcoxon signed-rank, Friedman and Student's $(t)$ tests for continuous variables. For testing hypothesis of independence, the Chi-square test was used.

The level of statistical significance by testing statistical hypothesis was 0.05 .

\section{Results}

Baseline characteristics of the study participants are presented in table 1 . The group consisted of 10 junior and 6 senior EM residents. Mean participant age was $26,4 \pm 1,75$ years. More than half of EM residents had never practiced mindfulness or meditation before. Seven were active smokers, more than a third consumed alcoholic beverages on a weekly basis.

Group HRV data is presented in figures 1 and 2. Two participants from group A failed continue participation in the study in the $2^{\text {nd }}$ month due to sick leave. Although clinically significant differences and fluctuations can be noted visually, we failed to identify any statistical significance in day-to-day basis or when comparing groups $\mathrm{A}$ and $\mathrm{B}$. Also, the day-to-day group HRV readings did not differ statistically significantly after cross-over of interventions. Interestingly, after pooling the pre-shift and post-shift HRV data, we identified differences of statistical significance where, paradoxically, post-shift HRV readings were higher $(\mathrm{p}=0.028$, $\mathrm{p}<0,05$ ).

Some of the exemplary individual pre-shift HRV trends are depicted in figures 3 and 4. Individual differences and big fluctuations in dayto-day HRV readings can be easily noted from the charts. Multiple incidents where day-to-day HRV values ranged from 30 to 80 in the same individual participant were noted.

\section{Discussion}

The absolute HRV values of EM residents were much lower than what we anticipated before the study, having in mind the young age of study participants. This indicates inadequate physical and mental preparedness for working conditions awaiting EM residents in the ERs. Very few participants indicated they are physically active more than once a week. A substantial amount were active smokers or consumed high amounts of caffeine daily. These factors contribute to lower stress resilience and longer 
HRV recovery times $[16,17,18,19]$.

We identified clinically significant fluctuations in dayto-day HRV readings of individual EM residents. This is an indicator of impaired autonomic nervous system balance, poor stress resilience and higher risk for developing burnout. If such variations were witnessed in professional athletes, they would be suspended from further training in fear of overload, whereas this mainly goes undetected (or ignored) in the medical field, where over-worked and under-resilient healthcare workers are constantly face with life or death decisions.

We did not identify superiority of the short, guided meditations in increasing EM residents' HRV values when compared to listening to relaxation music in the morning. This does not mean to say that guided meditations and relaxation techniques fail to increase stress resilience in general. Rather, such methods are mostly unfamiliar to healthcare workforce, which limits their applicability in a study setting. In fact, we received feedback from the study participants about not feeling pleasant doing the guided breathing or attention focusing techniques, which resulted in not complying with study protocol in some cases.

Main factors that pose limitations to our study are group sizes of the participants and the quality control of prescribed relaxation techniques. There is a crucial need of large scale studies which look into the effects of mindfulness techniques, physical activities, nutritional and dietary modifications in optimising healthcare specialists' performance.

Advices on how to stay healthy in EM are popular among emergency bloggers and FOAM community of the specialty [20]. However, the widespread of culture of health needs to happen in the education of healthcare specialists, if we want to provide the health sector with sustainable and stress-resilient workforce. The paradigm shift of precision performance and human performance optimisation that is underway in the military, needs to happen in the medical setting as well. We cannot build a strong system on strained individuals.

\section{Conclusion}

Our findings suggest the lack of autonomic nervous system balance among EM residents, as indicated by big fluctuations in their day-to-day HRV trends. During the course of the study, the HRV fluctuations did not stabilise, indicating the limited use of our selected short relaxation techniques (daily listening to relaxation music or performing a guided meditation) to increase residents' stress resilience. We also identified paradoxical findings of higher post-shift HRV readings among the trainees which could be true due to unique population in the setting of EM.

These findings prompt for further research to identify fea- sible monitoring methods and interventions that can increase the well-being and stress resilience of healthcare specialists, especially in the field of EM.

\section{References}

1. Amirian I, Toftegard Andersen L, Rosenberg J, Gogenur I. Decreased heart rate variability in surgeons during night shifts. Can J Surg 2014 Oct;57(5):300-304.

2. Atanes AC, Andreoni S, Hirayama MS, Montero-Marin J, Barros VV, Ronzani TM. et al. Mindfulness, perceived stress, and subjective well-being: a correlational study in primary care health professionals. BMC Complement Altern Med 2015 Sep 2;15:303-015-0823-0.

3. Bazarko D, Cate RA, Azocar F, Kreitzer MJ. The impact of an innovative mindfulness-based stress reduction program on the health and well-being of nurses employed in a corporate setting. J Workplace Behav Health 2013 Apr;28(2):107-133.

4. Romani M, Ashkar K. Burnout among physicians. Libyan J Med 2014 Jan;9(1):23556.

5. Aherne D, Farrant K, Hickey L, Hickey E, McGrath L, McGrath D. Mindfulness based stress reduction for medical students: optimising student satisfaction and engagement. BMC Med Educ 2016 Aug 18;16(1):209-016-0728-8.

6. Barbosa P, Raymond G, Zlotnick C, Wilk J, Toomey R,3rd, Mitchell J,3rd. Mindfulness-based stress reduction training is associated with greater empathy and reduced anxiety for graduate healthcare students. Educ Health (Abingdon) 2013 Jan-Apr;26(1):9-14.

7. Mahoney S, Sladek RM, Tim Neild T. A longitudinal study of empathy in pre-clinical and clinical medical students and clinical supervisors. BMC Med Educ 2016; 16:270.

8. Russell A, Deuster PA. Human performance optimization and precision performance: the future of special operations human performance efforts. J Spec Oper Med. Spring 2017;17(1):80-89.

9. Deuster PA, O'Connor FG. Human performance optimization: culture change and paradigm shift. J Strength Cond Res 2015 Nov;29 Suppl 11:S52-6.

10. Henning MA, Sollers J, Strom JM, Hill AG, Lyndon MP, Cumin D. et al. Junior doctors in their first year: mental health, quality of life, burnout and heart rate variability. Perspect Med Educ 2014 Apr;3(2):136-143.

11. Lu WC, Tzeng NS, Kao YC, Yeh CB, Kuo TB, Chang CC. et al. Correlation between health-related quality of life in the physical domain and heart rate variability in asymptomatic adults. Health Qual Life Outcomes 2016 Oct 21;14(1):149.

12. Muaremi A, Arnrich B, Troster G. Towards measuring stress with smartphones and wearable devices during workday and sleep. Bionanoscience 2013;3:172-183.

13. Rubik B. Effects of a passive online software application on heart rate variability and autonomic nervous system balance. J Altern Complement Med 2017 Jan; 23(1):68-74.

14. de Bruin EI, van der Zwan JE, Bogels SM. A RCT comparing 
daily mindfulness meditations, biofeedback exercises, and daily physical exercise on attention control, executive functioning, mindful awareness, self-compassion, and worrying in stressed young adults. Mindfulness (N Y) 2016;7(5):1182-1192.

15. de Vente W, van Amsterdam JG, Olff M, Kamphuis JH, Emmelkamp PM. Burnout is associated with reduced parasympathetic activity and reduced hpa axis responsiveness, predominantly in males. Biomed Res Int 2015;2015:431725.

16. Svendsen JL, Osnes B, Binder PE, Dundas I, Visted E, Nordby $\mathrm{H}$. et al. Trait self-compassion reflects emotional flexibility through an association with high vagally mediated heart rate variability. Mindfulness (N Y) 2016;7(5):1103-1113.

17. Teisala T, Mutikainen S, Tolvanen A, Rottensteiner M, Leskinen T, Kaprio J. et al. Associations of physical activity, fitness, and body composition with heart rate variability-based indicators of stress and recovery on workdays: a cross-sectional study. J Occup Med Toxicol 2014 Apr 18;9:16-6673-9-16. eCollection 2014.

18. van der Zwan JE, de Vente W, Huizink AC, Bogels SM, de Bruin EI. Physical activity, mindfulness meditation, or heart rate variability biofeedback for stress reduction: a randomized controlled trial. Appl Psychophysiol Biofeedback 2015 Dec;40(4):257-268.

19. Dong J. The role of heart rate variability in sports physiology. Exp Ther Med 2016 May;11(5):1531-1536.

20. Poonja ZM. et al. (2017). Healthy in EM Archives - ALiEM. [online] ALiEM. Available at: https:/www.aliem.com/category/non-clinical/healthy-in-em/ [Accessed 24 Dec. 2017].

\section{SKUBIOSIOS MEDICINOS REZIDENTAI NETURI REIKIAMO AUTONOMINĖS NERVU SISTEMOS BALANSO IR TRUMPUৃ RELAKSACINIU TECHNIKŲ NEUŽTENKA TAM IŠSPRĘSTI}

M. Gedminas, L. Neimanas, D. Vaitkaitis, N. Jasinskas, V. Šaferis, K. Stašaitis, P. Dobožinskas, A. Mačiukas

Raktažodžiai: širdies veiklos variabiliškumas, perdegimo sindromas, skubioji medicina, atsparumas stresui, rezidentūros studijos, žmogaus veiklos optimizavimas.

Santrauka
Tyrimo objektas. Širdies ritmo variabiliškumas (ŠRV) yra objektyvus ir lengvas tyrimo metodas, galintis matuoti autonominès nervų sistemos balansą, nuo ko priklauso asmens gebejjimas valdyti stresą. ŠRV yra plačiai naudojamas profesionalaus sporto bei karybos sektoriuose, siekiant optimalių veiklos rezultatų ir išvengiant perdegimo sindromo. Mūsų tyrimo tikslas buvo naudojantis ŠRV nustatyti skubiosios medicinos (SM) rezidentų autonominès nervų sistemos balansą bei trumpų atsipalaidavimo metodikų tinkamumą padidinant gydytojų atsparumą stresui.

Metodai. Atlikome dviejų mènesių trukmès randomizuotą dvigubai aklą kryžminị tyrimą. SM rezidentai buvo suskirstyti ị intervencijos (A) ir kontrolès grupes (B). Kontrolès grupès tiriamieji kiekvieną rytą klausẻ 12 min. trukmès relaksacinės muzikos ịrašą, o intervencinès grupès - kiekvieną rytą atliko $12 \mathrm{~min}$. trukmės vedamą meditaciją, kurioje buvo ritmiško kvėpavimo bei dèmesio sukaupimo komponentų. Po mėnesio ịvykdytas intervencijų apkeitimas.

Rezultatai. Sudèjus visus ŠRV duomenis ,prieš budejjimąa ir „po budejjimo“, gauti statistiškai reikšmingi rezultatai - ŠRV reikšmès po budejjimo buvo aukštesnès $(\mathrm{p}=0,028, \mathrm{p}<0,05)$. Analizuojant individualias ŠRV kreives, pastebèti labai ženklūs svyravimai kasdienèse rezidentų ŠRV reikšmėse. Mums nepavyko nustatyti trumpų relaksacinių technikų ịtakos SM rezidentų autonominès nervų sistemos balansui.

Išvados. Tyrimo rezultatai rodo sutrikusị autonominès nervų sistemos balansą tarp SM rezidentų. Tyrimo eigoje stebimųjų ŠRV kreivès nesidarè stabilesnès, todèl negalima teigti, jog parinktos relaksacinès technikos turejjo įtaką SM rezidentų streso atsparumui. Nustatėme netikètus radinius - santykinai didesnes ŠRV reikšmes „po budèjimo“ - tai galima sieti su unikalia populiacija, dirbančia skubios pagalbos skyriuose.

Adresas susirašinèti: mart.gedminas@gmail.com

Gauta 2018-01-24 